\title{
New Public Management bij Nederlandse overheids- en non-profit organisaties: stand van zaken
}

\section{Frank Verbeeten}

SAMENVATTING Veel overheidsorganisaties hebben in de afgelopen jaren (elementen van) New Public Management (NPM) ingevoerd. Op dit moment is echter nog onduidelijk in hoeverre overheidsorganisaties bepaalde NPM-instrumenten (strategische planning, prestatiemeting en -beloning) gebruiken. De resultaten van dit onder werkgevers van studenten van het Public Governance MBA van Universiteit Nyenrode uitgevoerd onderzoek suggereren dat de missie en doelstellingen van Nederlandse overheids- en non-profit organisaties duidelijk zijn geformuleerd, maar dat zij moeite hebben met het meetbaar maken van hun doelstellingen. Met name hoeveelheids- en kwaliteitsmaatstaven worden gebruikt; efficiency- en effectmaatstaven worden veel minder gehanteerd. Bovendien wordt de beloning van ambtenaren nauwelijks gebaseerd op de geleverde prestaties. Gesteld kan worden dat Nederlandse overheids- en non-profit organisaties de eerder genoemde instrumenten uit het NPM-model (strategische planning, prestatiemeting en -beloning) minder toepassen dan Angelsaksische agentschappen. Onder de Nederlandse overheidsorganisaties blijkt dat gemeenten de eerder genoemde instrumenten uit het NPM-model weer minder toepassen dan andere publieke sectoren.

\section{Inleiding}

Het presteren van de Nederlandse overheids- en nonprofit organisaties staat in de belangstelling. Bij de

Dr. F.H.M. Verbeeten MBA is als associate professor verbonden aan Universiteit Nyenrode. Met dank aan Prof. Dr. H. Ebbers en Drs. J.A. ten Rouwelaar voor eerdere opmerkingen bij dit artikel. Ook dank aan de studenten van het PG MBA 1 en 2 van Nyenrode voor de geleverde bijdrage aan de dataverzameling. rijksoverheid is het project 'Van Beleidsbegroting Tot Beleidsverantwoording' (VBTB) ingevoerd, binnen gemeenten werkt men met het Beleids- en BeheersInstrumentarium (BBI), en ook in diverse andere overheids- en non-profit organisaties zijn dergelijke initiatieven opgestart teneinde de prestaties inzichtelijk te maken en verantwoording af te leggen omtrent het gevoerde beleid. Het streven naar betere verantwoordingscijfers past in het streven naar een 'nieuwe' overheid: efficiënter en effectiever. Deze trend is in de afgelopen jaren ingezet en staat bekend onder de naam 'New Public Management' (NPM). De gedachte is dat door het definiëren van duidelijke beleidsdoelstellingen en het invoeren van prestatiemeting en beloning de overheid beter kan functioneren. Op dit moment bestaat echter weinig zicht op het al dan niet doorvoeren van de diverse NPM-instrumenten in Nederlandse overheids- en non-profit (ONP) organisaties. Kwantitatief empirisch onderzoek hiernaar is beperkt voorhanden en voornamelijk afkomstig uit Angelsaksische landen ${ }^{1}$. In dit artikel worden de onderzoeksresultaten gepresenteerd van een onder werkgevers van studenten van het Public Governance MBA van de Universiteit Nyenrode in Nederland uitgevoerd onderzoek.

De resultaten van dit onderzoek geven aan dat Nederlandse overheidsorganisaties instrumenten uit het NPM-model (strategische planning, prestatiemeting en -beloning) minder toepassen dan Angelsaksische agentschappen. Voorzover van prestatiemaatstaven gebruik wordt gemaakt zijn dat hoeveelheids- en kwaliteitsmaatstaven; efficiency- en effectiviteitsmaatstaven worden veel minder gehanteerd. De beloning van ambtenaren wordt niet of nauwelijks gebaseerd op de gerealiseerde prestaties. Ten slotte blijkt dat gemeenten de eerder genoemde instrumenten uit het NPM-model weer minder toepassen dan andere publieke sectoren (rijksoverheid en andere overheidsorganisaties als ziekenhuizen en sociale zekerheid). 
De opbouw van dit artikel is als volgt. In de volgende paragraaf wordt ingegaan op de theoretische achtergronden van NPM. Vervolgens komt in paragraaf 3 de methodologie van het onderzoek aan de orde, waarna de resultaten worden gepresenteerd. Dit artikel wordt afgesloten met een aantal conclusies.

\section{Theorie: Progressive Public Administration versus New Public Management}

In de afgelopen twintig jaar heeft er een omslag plaatsgevonden in het denken omtrent de aansturing van de publieke sector (Hood, 1995). Vanaf het eind van de 19de eeuw zijn overheidsorganisaties over het algemeen gestoeld op het 'progressive public administration' (PPA) model. Het PPA-model benadrukt twee managementdoctrines. De eerste betreft een duidelijke scheiding tussen de publieke en private sector voor wat betreft continuiteit, ethiek, organisatiestructuur, beloning en loopbaanstructuur. De tweede managementdoctrine betreft het aanbrengen van een buffer tussen politieke en ambtelijke zeggenschap door een uitgebreide structuur van procedures en regels, welke bedoeld is om corruptie en vooringenomenheid te beperken en rechtstreekse aansturing van de ambtelijke staf door politici te voorkomen. De gedachte achter het PPA-model is dat een dergelijke structuur voorkomt dat ambtenaren, welke geacht worden het algemeen belang na te streven, niet beïnvloed c.q. gecorrumpeerd zouden worden door incompetente en/of op eigenbelang gerichte politici die hun macht voor eigen doeleinden zouden willen gebruiken.

In de afgelopen jaren heeft er een aanzienlijke omslag plaatsgevonden in het denken omtrent de aansturing van de publieke sector (Budding en Groot, 2004). In vrijwel alle Angelsaksische landen (Nieuw-Zeeland, Australië, Groot-Brittannië, Verenigde Staten) is het New Public Management (NPM) model geïntroduceerd. Continentaal Europese landen (Duitsland, Frankrijk) hebben minder hervormingen in de aansturing van de publieke sector doorgevoerd, terwijl Nederland zich in de middengroep bevindt (Hood, 1995). Het NPM-model is gebaseerd op economische, rationele managementtheorieën en veronderstelt dat de verschillen tussen de publieke en private sector beperkt zijn, zodat managementinstrumenten die zich in de private sector hebben bewezen ook in de publieke sector kunnen worden gebruikt. De nadruk in het NPM-model ligt op het bereiken van resultaten, welke vooraf worden gedefinieerd, en veel minder op het naleven van regels en procedures. Bij de private instrumenten kan men denken aan het invoeren van strategische planningscycli (bedrijfsplannen) en het aansturen van overheidsorganisaties op basis van prestatiemeting (outputsturing) en prestatiebeloning.

Het idee achter NPM is dat de collectieve sector efficiënter en effectiever gaat werken (Budding en Groot, 2004; Groot en Van Helden, 2003), alsmede dat NPM bijdraagt aan de transparantie en legitimiteit van de overheid en bureaucratie voorkomt (De Bruijn, 2001). De samenleving weet of ze 'value for money' krijgt en als dat niet het geval is, kunnen maatregelen worden genomen om bij te sturen c.q. om publieke gelden anders in te zetten. Anderzijds zijn er diverse kanttekeningen te plaatsen bij het NPM-model omdat het geen recht zou doen aan de publieke sector. Zo is het maar de vraag of het politiek en maatschappelijk wenselijk is om doelen helder te formuleren en te kwantificeren; daarnaast zijn de door de organisatie voortgebrachte producten vaak moeilijk te typeren en zijn de producten niet homogeen (Hakvoort en Klaassen, 2002). Naast de meer technische problemen rond de meetbaarheid van de prestaties zou NPM ook strategisch gedrag kunnen stimuleren (alleen datgene verbeteren wat gemeten en beloond wordt, daadwerkelijke prestaties worden niet onderkend) alsook de professionaliteit van de ambtenaar aan kunnen tasten (Bordewijk en Klaassen, 2000). Ten slotte bestaat het gevaar dat NPM zich, gezien de beperkte meetbaarheid, te veel richt op de output en te weinig op de outcome (De Bruijn, 2001). Kortom, aan het introduceren van NPM-instrumenten ligt een aantal randvoorwaarden ten grondslag (De Bruijn, 2001).

Ondanks deze kanttekeningen bij NPM is het interessant om te bekijken in hoeverre instrumenten uit het NPM-gedachtegoed een plaats hebben verworven binnen Nederlandse overheids- en non-profit (ONP) organisaties. Deze studie richt zich met name op de strategische planning, prestatiemeting en beloning bij ONP-organisaties. Deze instrumenten zullen kort worden besproken; vervolgens zal in het empirisch deel worden bekeken in hoeverre zij in de praktijk worden toegepast.

\section{- Strategische planning}

De gedachte is dat het invoeren van strategische planning (bedrijfsplannen, jaarplannen, et cetera) zal leiden tot een efficiëntere toewijzing van middelen. Dergelijke strategische plannen zouden politici en ambtelijk managers moeten dwingen tot het formuleren van eenduidige en meetbare doelen, waar zij vervolgens op aangesproken zouden kunnen worden (Hyndman 
en Eden, 2000). Een dergelijke visie ontkent dat de variabiliteit van doelen en de daarop gebaseerde (politieke) interventies in de publieke sector veel groter is dan in het bedrijfsleven, alsmede dat de beoogde resultaten van ONP-organisaties (outcome) wellicht niet eenduidig te definiëren, te kwantificeren of te meten zijn (Hakvoort en Klaassen, 2002). In dit onderzoek wordt nagegaan in hoeverre ONP-organisaties met eenduidige en meetbare doelen werken (zie Mol, 1996; Hofstede, 1981; Ouchi, 1980).

\section{- Prestatiemeting}

Door het meten van prestaties zou de besluitvorming door ONP-managers kunnen verbeteren en de allocatie van middelen door politici kunnen verbeteren (Cavalluzzo en Ittner, 2004; Hyndman en Eden, 2000; Kloot en Martin, 2000; Bordewijk en Klaassen, 2000). Door de werkelijke resultaten te vergelijken met de geformuleerde doelstellingen zou beter beoordeeld kunnen worden wat de effectiviteit van het beleid is en waar aanvullende beleidsmaatregelen dan wel aanvullende middelen nodig zijn. In dit onderzoek wordt nagegaan welke prestatiemaatstaven daarbij worden gehanteerd.

\section{- Prestatiebeloning}

Wanneer prestatiemaatstaven beschikbaar zijn, zou kunnen worden overgegaan tot prestatiebeloning (Otley, 1999; Brickley et al.,1995). In dat geval kunnen managers zowel financieel als niet-financieel gemotiveerd worden tot het bereiken van de te realiseren prestaties. Bij prestatiebeloning moet niet alleen in termen van 'bonus' worden gedacht; immers, weinig ONP-organisaties kennen eenmalige extra uitkeringen in termen van aandelen, opties of 'cash'. Het betreft hier tevens beloning in de vorm van secundaire arbeidsvoorwaarden (het volgen van opleidingen) en aanzien (status binnen de organisatie). In dit onderzoek wordt nagegaan van welke prestatiemaatstaven de beloning (in brede zin) afhankelijk is. Hierbij kan worden aangetekend dat prestatiebeloning ingaat tegen de in het PPA-model gehanteerde doctrine dat de inzet van ambtenaren voor de publieke zaak niet te kwantificeren en dus ook niet te belonen is; immers, prestatiebeloning voor ambtenaren zou tot perverse effecten kunnen leiden (Hood, 1995).

Naar algemeen besef komt een oriëntatie op de resultaten in plaats van op de middelen in de collectieve sector slechts moeizaam van de grond ( $\mathrm{Mol}$ en De Kruijf, 2004). In mijn onderzoek wordt empirisch getoetst in hoeverre het NPM-gedachtegoed post heeft gevat bij Nederlandse ONP-organisaties. Daar- bij wordt onderscheid gemaakt naar het totale beeld, alsmede naar drie sectoren (rijksoverheid, lokale overheid en overige ONP-organisaties). De resultaten zullen, voorzover mogelijk, worden vergeleken met een aantal onderzoeken in andere landen (Cavalluzzo en Ittner, 2004; Hyndman en Eden, 2000; Kloot en Martin, 2000) en eerder Nederlands onderzoek binnen met name de gemeentelijke sector (Aardema, 2002; Ter Bogt, 2001a, 2001b; Bordewijk en Klaassen, 2000; Van Helden, 1998).

\section{Opzet onderzoek}

Data voor het onderzoek zijn verzameld door middel van een vragenlijst die is uitgezet bij de werkgevers van studenten van het Public Governance MBA op Universiteit Nyenrode. Gekozen is voor een schriftelijke vragenlijst omdat op die manier op een relatief goedkope en efficiënte wijze informatie omtrent een aantal NPM-instrumenten kan worden verzameld (Cooper en Schindler, 2003) ${ }^{2}$. In totaal zijn 104 (grotendeels) bruikbare vragenlijsten retour ontvangen ${ }^{3}$; in tabel 1 wordt een overzicht gegeven van de organisaties, naar omvang (aantal fte) en naar overheidssector.

\section{Tabel 1. Beschrijving steekproef}

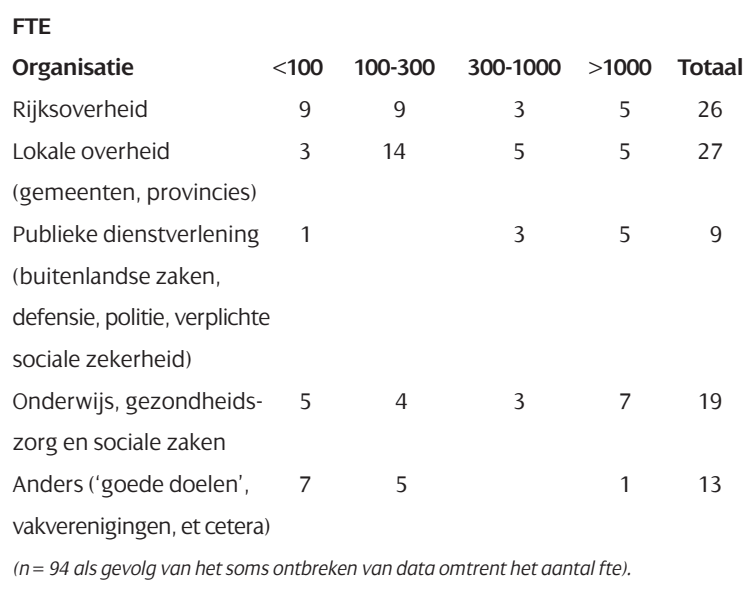

Binnen dit onderzoek wordt, zoals aangegeven, onderscheid gemaakt naar Rijksoverheid (RO), Lokale overheid (LO) en overige publieke organisaties (Overig). Deze laatste categorie omvat de organisaties uit publieke dienstverlening, onderwijs, gezondheidszorg en sociale zaken en andere organisaties. Deze samenvoeging is noodzakelijk omdat het anders niet mogelijk is om uitspraken te doen omtrent de verschillen tussen de verschillende categorieën ONP-organisaties. 
Bij de rijksoverheid betreft het deels agentschappen en zelfstandige bestuursorganen, deels andere organisaties (ministeries).

Respondenten zijn algemeen managers/directeuren (44\%), financieel managers (29\%), afdelingshoofden (15\%) en overige respondenten (13\%, onder wie hoofden $\mathrm{P} \& \mathrm{O}$ en beleidsmedewerkers $)^{4}$. Gemiddeld zijn de respondenten negen jaar werkzaam bij hun organisatie (mediaan: zes jaar) en vijf jaar werkzaam in hun huidige functie (mediaan: drie jaar). De data suggereren dat de respondenten goed geïnformeerd zijn omtrent de 'NPM-stand van zaken' in hun organisatie.

In de vragenlijst ${ }^{5}$ is zoveel mogelijk gebruikgemaakt van bestaande instrumenten. De variabelen die zijn gemeten betreffen de eenduidigheid en meetbaarheid van de doelstellingen, de vormgeving van het prestatiemeetsysteem en de maatstaven die worden meegenomen bij de evaluatie van managers. In de volgende tabellen worden de gemiddelde resultaten per sector (RO, LO, overig) gepresenteerd, alsmede de resultaten van de Kruskal-Wallis test (KW-test), die aangeeft of de resultaten onderling significant verschillen.

\section{Resultaten}

\subsection{Strategische planning}

Tabel 2 geeft weer in hoeverre organisaties van mening zijn dat hun doelstellingen eenduidig zijn geformuleerd, dan wel of hun doelstellingen meetbaar zijn.
Tabel 2 geeft weer dat de missie over het algemeen redelijk eenduidig is geformuleerd, vastgelegd en gecommuniceerd; ook zijn de doelstellingen over het algemeen gerelateerd aan de missie. Daar staat tegenover dat de doelstellingen niet altijd volledig weergeven welke resultaten moeten worden behaald en dat de doelstellingen niet altijd gerelateerd zijn aan de prestatiemaatstaven. Klaarblijkelijk worden er prestaties gemeten die niet relevant zijn voor het bereiken van de doelstellingen, dan wel wordt niet gemeten of bepaalde doelstellingen worden gehaald. Dit beeld komt overeen met de resultaten van een onderzoek van Hyndman en Eden (2000) onder Engelse agentschappen ${ }^{6}$; uit hun resultaten bleek eveneens dat niet alle doelstellingen worden gemeten en dat niet alle prestatiemaatstaven te relateren zijn aan geformuleerde (beleids)doelen.

Wat ook opvalt is dat lagere overheden over het algemeen lager scoren dan andere ONP-organisaties (RO, overig): zij hebben een statistisch significant minder eenduidige en gecommuniceerde missie, doelstellingen zijn minder gerelateerd aan de missie, het totaal aan doelstellingen geeft minder goed weer welke resultaten moeten worden behaald, en prestatiemaatstaven zijn minder gerelateerd aan de doelstellingen van de organisatie. Dit zou kunnen duiden op de mogelijkheid dat bij gemeenten de dagelijkse politiek wellicht meer invloed heeft op de bedrijfsvoering dan bij andere ONP-organisaties (zie bijvoorbeeld ook Ter Bogt, 2001b).

\section{Tabel 2. Missie en doelstellingen}

Kunt $u$, op basis van uw ervaringen binnen uw organisatie, aangeven in

hoeverre $u$ het eens bent met de volgende stellingen om trent de missie

en doelstellingen van uw organisatie?

Aantal waarnemingen ( $\mathrm{n}$ )

De missie van mijn organisatie is eenduidig geformuleerd

De missie van mijn organisatie is vastgelegd op papier en zowel

intern als extern gecommuniceerd

De doelstellingen van mijn organisatie zijn eenduidig gerelateerd aan

de missie van mijn organisatie

De doelstellingen van mijn organisatie zijn volledig gebaseerd op

kwantitatieve zaken (budget, productiviteit, aantallen, et cetera)

Het totaal aan doelstellingen geeft volledig weer welke resultaten mijn

organisatie dient te bereiken

De prestatiemaatstaven voor mijn organisatie zijn eenduidig gerelateerd

aan de doelstellingen van mijn organisatie

Responsmogelijkheid: 1 = volledig mee oneens, 2 = grotendeels mee oneens, $3=$ neutraal, $4=$ grotendeels mee eens, $5=$ volledig mee eens.
RO

LO

Overig

Totaal

KW-test

$\begin{array}{llll}31 & 27 & 45 & 103\end{array}$

3.71

$3.94 \quad 3.19$

4.16

4.11

103

3.82

3.82

$\begin{array}{llll}3.74 & 3.07 & 3.89 & 3.63\end{array}$

$\begin{array}{llll}2.42 & 2.67 & 2.07 & 2.33\end{array}$

$\begin{array}{llll}2.97 & 2.63 & 2.98 & 2.88\end{array}$

$\begin{array}{llll}2.87 & 2.33 & 2.82 & 2.71\end{array}$

$*^{* * *}, * * *=$ resultaat Kruskal-Wallis-test significant op $10 \%, 5 \%$ en $1 \%$ 
Tabel 3. Soort prestatiemaatstaven

In welke mate bent $u$ het eens met de volgende stellingen om trent de prestatiemaatstaven voor uw organisatie?

Aantal waarnemingen $(\mathrm{n})$

Mijn organisatie hanteert prestatiemaatstaven die intern aangeven hoeveel

we produceren of hoeveel diensten we leveren

Mijn organisatie hanteert prestatiemaatstaven die intern aangeven in

hoeverre we efficiënt opereren

Mijn organisatie hanteert prestatiemaatstaven die intern aangeven in

hoeverre onze klanten/afnemers tevreden zijn

Mijn organisatie hanteert prestatiemaatstaven die intern de kwaliteit

van de geleverde diensten of producten aangeven

Mijn organisatie hanteert prestatiemaatstaven die intern aangeven

welke effecten we gerealiseerd hebben

Mijn organisatie hanteert prestatiemaatstaven die voor extern

betrokkenen inzichtelijk maakt of we onze beoogde resultaten ook

daadwerkelijk bereikt hebben

Responsmogelijkheid: 1 = volledig mee oneens, 2 = grotendeels mee oneens, $3=$ neutraal, 4 = grotendeels mee eens, $5=$ volledig mee eens.

${ }^{*},{ }^{* *},{ }^{* * *}=$ resultaat Kruskal-Wallistest significant op $10 \%, 5 \%$ en $1 \%$.

$\mathrm{a}=$ verschil tussen $\mathrm{RO}$ en LO significant op $10 \%$ niveau:

$\mathrm{b}=$ verschil tussen $\mathrm{LO}$ en Overig significant op $10 \%$ niveau.

\subsection{Prestatiemaatstaven}

Tabel 3 geeft weer welke prestatiemaatstaven in de publieke sector worden gehanteerd.

Binnen de overheid worden met name hoeveelheidsmaatstaven gebruikt; daarnaast worden maatstaven gehanteerd die voor externe betrokkenen aangeven of de beoogde resultaten ook daadwerkelijk zijn bereikt. Dit komt met name omdat lokale overheden vertrouwen op hoeveelheidsmaatstaven; andere prestatiemaatstaven zijn minder ontwikkeld. Dit is consistent met de resultaten van Kloot en Martin (2000) onder Australische gemeenten: ook daar bleek dat met name hoeveelheidsmaatstaven en (in mindere mate) klanttevredenheid bij de lokale overheid het meest ontwikkeld zijn. In de Nederlandse gemeentelijke context concluderen ook Hakvoort en Klaassen (2002) dat gemeentelijke systemen met name gericht zijn op input en in mindere mate op output en outcome. De rijksoverheid lijkt een meer gevarieerd pakket van prestatiemaatstaven te hanteren. Opvallend is daarbij dat de rijksoverheid met name prestatiemaatstaven hanteert die voor externe betrokkenen inzichtelijk maken of de beoogde resultaten zijn bereikt. Dit komt overeen met het onderzoek van Cavalluzzo en Ittner (2004); ook daar worden met name hoeveelheidsmaatstaven en maatstaven voor de externe verantwoording gehanteerd.
Opvallend is ook dat de prestatiemaatstaven bij Amerikaanse agentschappen over het algemeen meer ontwikkeld zijn dan bij Nederlandse ONP-organisaties (zie Cavalluzzo en Ittner, 2004). Daarbij moet worden opgemerkt dat Angelsaksische agentschappen niet zonder meer kunnen worden gelijkgesteld aan een 'gemiddelde Nederlandse ONP-organisatie". Daarnaast is er een aanzienlijk verschil tussen de beoogde effecten en de verantwoording jegens externe partijen; klaarblijkelijk wordt niet gekozen voor de te bereiken einddoelstelling, maar voor subdoelstellingen (Boorsma et al., 1999). De vraag is of de gekozen maatstaven, die de managers van de desbetreffende eenheden kunnen beïnvloeden, wel aansluiten op de te bereiken effecten. Op het gebied van prestatiemaatstaven lijken rijksoverheid en overige organisaties de meest ontwikkelde prestatiemeetsystemen te hebben, al verschilt de wijze van inrichting. Ook hier blijft de lokale overheid enigszins achter voor wat betreft de invoering van het 'NPM-model'.

\subsection{Prestatiebeloning}

In het onderzoek is tevens nagegaan wat de relatie is tussen de door de organisatie geleverde prestaties en de beloning. Daarbij is het begrip beloning ruim geïnterpreteerd. In bijlage A zijn de per prestatiemaatstaf gehanteerde vragen opgenomen; in tabel 4 


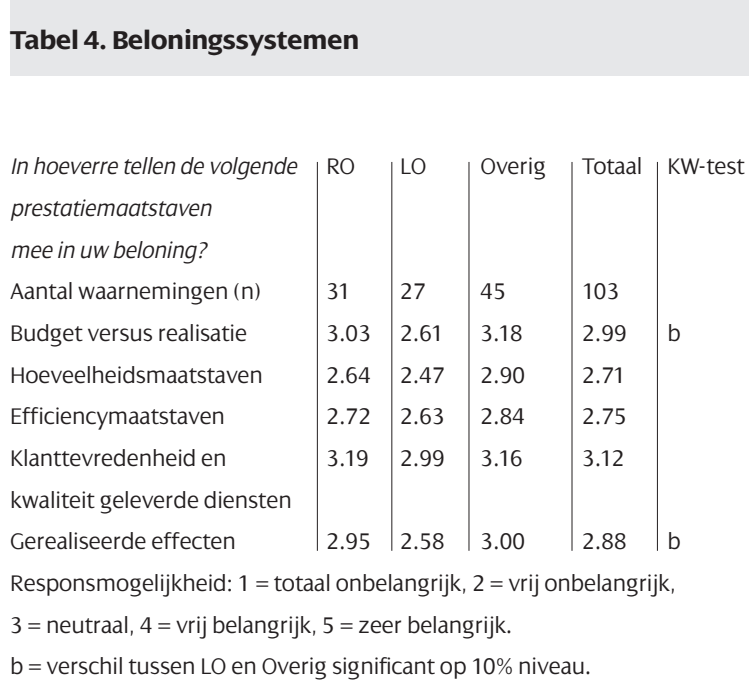

wordt het gemiddelde van deze vragen gepresenteerd. De beloning bij de overheid lijkt nauwelijks gebaseerd te zijn op 'harde' prestatiegegevens. Klanttevredenheid is enigszins belangrijk, de overige prestatiemaatstaven zijn nauwelijks belangrijk voor de beloning binnen overheidsorganisaties. Dit is overeenkomstig de kenmerken van het PPA-model: beloning van ambtenaren op basis van het prestatieniveau kan leiden tot ongewenste effecten en zou voorkomen moeten worden (zie Hood, 1995). Ook hier geldt weer dat bij de lokale overheid de beloning minder is gebaseerd op gegevens uit het prestatiemeetsysteem dan bij de overige twee sectoren. Tevens blijkt dat bepaalde soorten prestatiemaatstaven meer ontwikkeld zijn, terwijl de beloning in deze categorie minder van belang is. Zo zijn hoeveelheidsmaatstaven bijvoorbeeld goed ontwikkeld (zie tabel), maar deze zijn niet erg belangrijk voor de beloning van managers (zie tabel 4). Daarentegen zijn klanttevredenheids- en kwaliteitsmaatstaven minder ontwikkeld, maar belangrijker voor de beloning van overheidsmanagers. Het is derhalve de vraag of datgene wordt gemeten en beloond wat belangrijk is voor de organisatie. Een andere mogelijkheid is dat de beloning is gebaseerd op meer kwalitatieve beoordelingen. Zo heeft Ter Bogt (2001b) bijvoorbeeld geconstateerd dat het reageren op kortetermijnproblemen en op wensen van politici belangrijk is voor de evaluatie (en beoordeling) van managers in gemeenten (in aanvulling op de meer kwantitatieve outputinformatie).

Een laatste belangrijke constatering is dat overheidsorganisaties aangeven dat het belang van de maatstaven in de ogen van het management hoger is dan het belang van de maatstaf voor de beloning van managers. Dit betekent dat financiële incentives (veel) minder worden gebruikt binnen (Nederlandse) ONPorganisaties dan door het NPM-model wordt gepropageerd (zie Dixit, 1997; Rose-Ackerman, 1986).

\section{Discussie en conclusies}

De doelstelling van dit onderzoek is om inzichtelijk te maken wat de stand van zaken is voor wat betreft de invoering van instrumenten uit het NPM-model (strategische planning, prestatiemeting en -beloning) in de Nederlandse ONP-sector. De resultaten uit dit onderzoek zijn daartoe vergeleken met onderzoek uit Angelsaksische landen (zie Cavalluzzo en Ittner, 2004; Hyndman en Eden, 2000; Kloot en Martin, 2000), alsmede met de resultaten van eerdere Nederlandse studies (Ter Bogt, 2001; Bordewijk en Klaassen, 2000; Hakvoort en Klaassen, 2002; Aardema, 2002; Van Helden, 1998). Daartoe zijn, naast het gemiddelde over alle organisaties, ook de resultaten per sector (rijksoverheid, lagere overheid en 'overige ONP-organisaties) bekeken.

Uit het onderzoek blijkt dat Nederlandse ONP-organisaties hun doelstellingen als redelijk eenduidig en helder ervaren. Daarentegen blijkt de meetbaarheid van het bereiken van de doelstellingen nogal eens problemen op te leveren; klaarblijkelijk is het moeilijk om alle beoogde doelstellingen 'SMART's te formuleren, dan wel om het bereiken van deze doelstellingen op een eenvoudige en consistente wijze te meten. Consistent met eerder buitenlands (Cavalluzzo en Ittner, 2004; Kloot en Martin, 2000) en Nederlands onderzoek binnen gemeenten (Aardema, 2002; Hakvoort en Klaassen, 2002) is het gegeven dat prestatiemeetsystemen met name hoeveelheidsmaatstaven bevatten. Dit geeft ook aan dat er klaarblijkelijk een verschil bestaat tussen de effecten die men wil bereiken en de verantwoording die men jegens derden aflegt. De vraag rijst dan ook of alleen datgene gemeten wordt wat eenvoudig meetbaar is en of de te bereiken effecten uit het oog worden verloren. Als dat het geval is, zou sprake kunnen zijn van 'pseudo-control' (Hofstede, 1981): alle metertjes geven aan dat het goed gaat, maar ondertussen gaat er 'onderhuids' van alles mis.

Ook consistent met de (PPA-)literatuur is dat de beloning van ambtenaren niet of nauwelijks gebaseerd is op formele prestatiemaatstaven. Op zich is dit niet erg, omdat zo voorkomen wordt dat het eerder genoemde 'pseudocontrol' (verder) in de hand wordt gewerkt. Overheidsmanagers kunnen nu 'om de bereikte resultaten heen kijken' teneinde te beoordelen of medewerkers aan hun verplichtingen hebben 
voldaan (Vollaard, 2003). Aan de andere kant is ook bekend dat het stellen van ambitieuze, duidelijke en meetbare doelstellingen en het belonen op basis van het bereiken van de doelstellingen tot hogere prestaties leidt (zie Locke en Latham, 1990).

Als 'overall-conclusie' blijkt dat Nederlandse overheidsorganisaties in vergelijking met Angelsaksische agentschappen enigszins achterblijven in de toepassing van NPM-instrumenten. Ook blijkt dat, binnen de Nederlandse publieke sector, gemeenten de eerder genoemde instrumenten uit het NPM-model (strategische planning, prestatiemeting en -beloning) veel minder toepassen dan andere organisaties in de publieke sector. Deze laatste constatering is consistent met eerder onderzoek in deze sector (Aardema, 2002; Bordewijk en Klaassen, 2000). Door de literatuur (Hakvoort en Klaassen, 2002) wordt aangegeven dat dit mogelijk wordt veroorzaakt door de onwenselijkheid van het definiëren van heldere en eenduidig meetbare doelstellingen, de grote impact van de politiek op de bedrijfsvoering en de samenhang tussen de verschillende onderdelen van lokale overheden (de 'heterogeniteit' van producten).

Uit dit onderzoek komt nog een aantal andere mogelijkheden voor vervolgonderzoek voort. De eerste betreft de vraag in hoeverre organisaties in de publieke sector hun doelstellingen niet meetbaar willen, dan wel kunnen maken. Als overheden hun doelstellingen niet meetbaar willen maken, zal het verplicht invoeren van VBTB tot een andere, wellicht meer effectieve aansturing van publieke organisaties leiden. Als ONPorganisaties hun doelstellingen niet meetbaar kunnen maken, zal introductie van instrumenten uit het NPM-model leiden tot pseudo-control met wellicht als gevolg het vernietigen van maatschappelijke waarde. Een met het voorgaande samenhangende onderzoeksvraag zou kunnen zijn of de diverse publieke organisaties op de meest effectieve wijze gebruikmaken van een mix van controls (oftewel, zijn output, social en behavioral controls op elkaar afgestemd; zie Ouchi, 1980).

\section{Literatuur}

Aardema, H., (2002), Doorwerking van BBI, Bestuur \& Management Consultants, Leusden.

Bogt, H.J. ter, (2001a), Bronnen van control-informatie voor politieke bestuurders, in: Maandblad voor Accountancy en Bedrijfseconomie, vol. 75, no. 12, pp. 525-538.

Bogt, H. ter, (2001b), Politicians and output-oriented performance evaluation in municipalities, in: The European Accounting Review, vol. 10, no. 3, pp. 621-643.
Boorsma, P.B., F.C.M.M. Maessen en J.A. Schild, (1999), Van beleidsbegroting tot beleidsverantwoording in relatie tot beleidsanalyse en prestatiebegroting: een historische vergelijking van een beleidsanalytisch perspectief, in: Beleidsanalyse, vol. 1, no. 2, pp. 15-28.

Bordewijk, P. en H.L. Klaassen, (2000), Wij laten ons niet kennen: Een onderzoek naar het gebruik van kengetallen bij negen grotere gemeenten, VNG Uitgeverij, Den Haag.

Brickley, J., C. Smith en J. Zimmerman, (1995), The economics of organizational architecture, in: Journal of Applied Corporate Finance, vol, 8 , no. 2, pp. 19-31.

Bruijn, H. de, (2001), Prestatiemeting in de publieke sector, Uitgeverij Lemma, Utrecht.

Budding, G.Tj. en T.L.C.M. Groot, (2004), New Public Management: Een zoektocht naar de excellente overheid, in: Accounting, vol. 108, no. 3, pp. 2-4.

Cavalluzzo, K.S. en C.D. Ittner, (2004), Implementing performance measurement innovations: evidence from government, in: Accounting Organizations \& Society, vol. 29, no. 3-4, pp. 243-267.

Cooper, D.R. en P.S. Schindler, (2003), Business Research Methods, $8^{\text {th }}$ International Edition, McGraw-Hill, Boston.

Centraal Plan Bureau, (2004), Centrale doelen, decentrale uitvoering, CPB Document no. 45, januari 2004.

Creation, Review and Dissolution of Executive Agencies, (2004),

http://www.civilservice.gov.uk/improving_services/agencies_and_public _bodies/publications/pdf/exec-agencies_guidance_april04.pdf.

Dewatripont, M., I. Jewitt en J. Tirole, (1999), The economics of career concern, part II: application to missions ad accountability of government agencies, in: Review of Economic Studies, vol. 66, pp. 199-217.

Dixit, A., (1997), Power of incentives in private versus public organizations, in: American Economic Review, vol. 87, no. 2, pp. 378-382.

Dranove, D., D. Kessler, M. McClellan en M. Satterthwaite, (2003), Is More Information Better? The Effects of 'Report Cards' on Health Care Providers, in: Journal of Political Economy, vol. 11, no. 3, pp. 555-588.

Groot, T.L.C.M. en G.J. van Helden, (2003), Financieel management van non-profit organisaties, Stenfert Kroese, Groningen.

Hakvoort, J.L.M. en H.L. Klaassen, (2002), Publieke performance in beeld, Working paper ten behoeve van NPM seminar Nyenrode, Erasmus Universiteit Rotterdam.

Helden, G.J. van, (1998), BBI in de praktijk, Shaker Publishing, Maastricht. Hofstede, G., (1981), Management control of Public and Not-for-Profit Activities, in: Accounting, Organizations \& Society, vol. 6, no. 3, pp. 193-211. Hood, C., (1995), The 'New Public Management' in the 1980s: variations on a theme, in: Accounting, Organizations and Society, vol. 20, no. 2/3, pp. 93-109.

Hyndman, N. en R. Eden, (2000), A study of the coordination of mission, objectives and targets in UK executive agencies, in: Management Accounting Research, 2000, vol. 11, pp. 175-191.

Jansen, E.P., (2001), Het gebruik van prestatie-informatie: Casestudies bij Gemeentelijke Sociale Diensten, in: Tijdschrift voor Bedrijfsadministratie, vol. 105, januari/februari 2001, nr. 1239, pp. 2-11.

Keating, A.S., (1997), Determinants of divisional performance evaluation practices, in: Journal of Accounting and Economics, vol. 24, pp. 243-273.

Kloot, L. en J. Martin, (2000), Strategic Performance management: A balanced approach to performance management issues in local govern- 
ment, in: Management Accounting Research, 2000, vol. 11, pp. 231-251. Kravchuk, R.S. en R.W. Schank, (1996), Designing effetive performancemeasurement systems under the government performance and results act of 1993, in: Public Administration Review, vol. 56, no. 4, pp. 348-358. Locke, E.A. en G.P. Latham, (1990), A Theory of Goal Setting \& Task Performance, Prentice Hall, Englewood Cliffs, NJ.

Mol, N.P. en J.A.M. de Kruijf, (2004), Resultaatgerichte sturing in overheidsorganisaties, in: Accounting, vol. 108, no. 3, pp. 13-20.

Mol, N.P., (1996), Performance Indicators in the Dutch department of defence, in: Financial Accountability \& Management, vol. 12, no. 1, pp. 71-81. OMB, (2004), Government Performance Results Act of 1993, zie http://www.whitehouse.gov/omb/mgmt-gpra/ 2004

Otley, D., (1999), Performance management: a framework for management control systems research, in: Management Accounting Research, vol. 10, pp. 363-382.

Ouchi, W.G., (1980), Markets, Bureaucracies and Clans, in: Administrative Science Quarterly, vol. 25, pp. 129-141.

Rose-Ackerman, S., (1986), Reforming public bureaucracy through economic incentives?, in: Journal of Law, Economics, and Organization, vol. 2, pp. 131-161.

Verbeeten, F.H.M., (2003), The Relation between Goals, Performance management and Performance of Non-profit organizations, Working paper, Universiteit Nyenrode.

Verbeeten, F.H.M., (2004), Leidt de toepassing van NPM-technieken tot betere prestaties? Een empirisch onderzoek, in: Accounting, vol. 108, no. 3, pp. 21-28.

Vollaard, B., (2003), Performance contracts for police forces, CPB Document, no. 31, May 2003.

\section{Noten}

1 Uitzonderingen zijn de artikelen van Mol en De Kruijf, 2004; Jansen, 2001; Ter Bogt, 2001a, 2001b.
2 Andere mogelijkheden zijn onder meer persoonlijke en/of telefonische interviews, respectievelijk analyse archiefdata of planning- en controldocumenten; zie bijvoorbeeld Bordewijk en Klaassen (2000); Van Helden (1998). Nadeel van interviews is dat niet alle gewenste respondenten (hoger management) even toegankelijk zijn en dat beïnvloeding door de interviewer mogelijk is. Nadeel van de documentanalyse is dat de informatie in de documenten inmiddels achterhaald kan zijn, de gewenste informatie moeilijk te vinden is en dat deze methode onvoldoende aangeeft in hoeverre de desbetreffende data van belang zijn in de evaluatie en de besluitvorming (zie ook Cooper en Schindler, 2003, voor een bespreking van onderzoeksmethoden).

3 Een nadeel van de survey methode ten opzichte van interviews of documentanalyse is dat respondenten sociaal wenselijke antwoorden geven. Uit een analyse van de responses blijkt echter dat de scores vrijwel altijd variëren tussen 1 (soms 2 ) en 5 (soms 4). Dit suggereert dat de antwoorden de daadwerkelijke situatie, en niet zozeer de sociaal wenselijke situatie, weergeven.

4 Gecontroleerd is of de antwoorden zoals die in dit artikel zijn weergegeven, significant verschillen per groep respondenten. Op een enkele uitzondering na is dit niet het geval.

5 De volledige vragenlijst is op te vragen bij de auteur van dit artikel.

6 De Engelse agentschappen in dit onderzoek dienen zich te houden aan diverse richtlijnen, onder meer op het gebied van strategische plannen en prestatiemeting (zie bijvoorbeeld http://www.civilservice. gov.uk/improving_services/agencies_and_public_bodies/publications/ pdf/exec-agencies_guidance_april04.pdf).

7 Amerikaanse agentschappen moeten voldoen aan richtlijnen die in de 'Results Act' zijn opgenomen; in de Results Act staat onder meer dat agentschappen moeten werken met een strategisch plan (inclusief missie, doelstellingen en strategie) en met prestatiemaatstaven die aangeven in hoeverre de doelstellingen gerealiseerd worden (OMB, 2004).

8 SMART staat voor Simple, Measurable, Attainable, Realistic en Timebound.

\section{Bijlage A. Onderdeel beloningsmaatstaven}

Met betrekking tot beloningssystemen is gevraagd naar de relatie tussen de door de organisatie geleverde prestaties en de beloning. Voor een aantal prestatiemaatstaven (budget versus realisatie, hoeveelheidsmaatstaven, kwaliteitsmaatstaven, et cetera) is gevraagd om aan te geven of, en zo ja op welke wijze, zij meetellen in de beloning. Daarbij zijn per prestatiemaatstaf de volgende vragen gehanteerd (gebaseerd op Keating,1997):

\begin{tabular}{|c|c|c|c|c|c|}
\hline \multirow[t]{2}{*}{ Budget versus realisatie } & \multicolumn{4}{|c|}{ Totaal onbelangrijk } & \multirow{2}{*}{$\begin{array}{l}\text { Zeer belangrijk } \\
5\end{array}$} \\
\hline & 1 & 2 & 3 & 4 & \\
\hline \multicolumn{6}{|l|}{ Belang dat het hoger management aan de maatstaf hecht } \\
\hline \multicolumn{6}{|l|}{ Belang van de maatstaf in besprekingen met hoger management } \\
\hline \multicolumn{6}{|l|}{ Mate waarin de maatstaf uw succes weerspiegelt in de ogen van het hoger management } \\
\hline \multicolumn{6}{|l|}{ Mate van aandacht van het hoger management voor de maatstaf } \\
\hline Belang van de maatstaf voor uw totale beloning (salaris, bonus, promotiemogelijkheden, etc.) & & & & & \\
\hline
\end{tabular}

